\title{
Molecular assessment of atpase6 mutations associated with artemisinin resistance among unexposed and exposed Plasmodium falciparum clinical isolates to artemisinin-based combination therapy
}

Sedigheh Zakeri ${ }^{1 *}$, Samaneh Hemati ${ }^{2}$, Sakineh Pirahmadi ${ }^{1}$, Mandana Afsharpad ${ }^{1}$, Ahmad Raeisi ${ }^{3,4}$ and Navid D Djadid ${ }^{1}$

\begin{abstract}
Background: Artemisinin-based combination therapy (ACT) is the mainstay of global efforts for treatment of Plasmodium falciparum malaria, but decline in its efficacy is the most important obstacle towards malaria control and elimination. Therefore, the present molecular analysis provides information on putative mutations associated with artemisinin resistance in $P$. falciparum clinical population unexposed and exposed to artesunate 4 years after adoption of ACT as the first-line anti-malarial therapy in Iran.
\end{abstract}

Methods: In this study, blood samples $(n=226)$ were collected from uncomplicated $P$. falciparum-infected patients from different health centers of Chabahar district in Sistan and Baluchistan province in the south-eastern part of Iran, during 2003 to 2010. All collected isolates were analysed for putative candidate mutations (TTA) L263E (GAA), (GAA) E431K (AAA), (GCA) A623E (GAA) and (AGT) S769N (AAT) of pfatpase6 gene using nested PCR/RFLP, followed by sequencing. Furthermore, the gene copy number was assessed by real-time quantitative PCR (RT-qPCR) in the presence of SYBR green.

Results: Neither the pfatpase6 L263E nor the A623E mutation was detected among all examined isolates. The E431 K mutation was found in $23 \%$ of the analysed samples unexposed to ACT; however, it was detected in $17.8 \%$ (34/191) of $P$. falciparum isolates exposed to artesunate after 2007. High frequency of this single nucleotide polymorphisms (SNP) (overall 18.6\%) among both examined groups ( $X^{2}$ test, $P>0.05$ ) indicated that this SNP should be considered as an unrelated mutation to artemisinin resistance. In contrast, S769N mutation was not detected in unexposed isolates; however, it was found in 2.6\% (5/191), four years after introduction of ACT in this malaria setting. Also, detected SNPs were not significantly frequent in both unexposed and exposed examined isolates $\left(X^{2}\right.$ test, $\left.P>0.05\right)$. Investigation in the copy number of pfatpase6 gene revealed a similar number of copy $(n=1)$ as in an isolate sensitive to artemisinin.

Conclusion: Taken together, the results suggest, in particular, that pfatpase6 S769N gene needs more consideration for its possible association with artesunate resistance among $P$. falciparum isolates.

\footnotetext{
*Correspondence: zakeris@yahoo.com

${ }^{1}$ Malaria and Vector Research Group (MVRG), Biotechnology Research Center (BRC), Pasteur Institut, P.O. Box 1316943551, Tehran, Iran

Full list of author information is available at the end of the article
} 


\section{Background}

Plasmodium falciparum resistance is one of the most important public health issues in many endemic countries in the recent years. In the absence of a fully-protective anti-malarial vaccine, malaria control heavily relies on the use of drugs for treatment or prophylaxis. However, the increasing failure of the predominantly used and safe drugs, especially chloroquine (CQ) and sulphadoxinepyrimethamine (SP), has been a serious obstacle towards global malaria control. Consequently, to overcome the resistance problem, the World Health Organization (WHO) and health authorities in malaria endemic countries recommend the use of a therapeutic combination. They recommend the use of artemisinin derivatives in combination with other drugs (ACT) in order to provide a better efficacy and avoidance of resistance nationwide [1,2]. As a result, following increased CQ and SP resistance, artemisinin and its derivatives gradually became the mainstay of falciparum malaria therapy. Besides, previous experiences with other anti-malarial drugs showed that resistance appears after long-term use. Recent reports of the reduced artemisinin sensitivity of $P$. falciparum parasites in known foci in Cambodia and Thailand, and new suspected foci in Myanmar and Vietnam may suggest a decline in ACT efficacy [3-5]. Therefore, due to the essential role of ACT in malaria control and elimination, it is crucial to have a regular surveillance of resistance to determine whether resistance to artemisinin has developed or not.

The molecular mechanisms involved in underlying resistance to artemisinin derivatives are not clearly understood and identification of molecular markers would provide insight into these mechanisms. Also, up to the present, artemisinin resistance has not been clinically documented, but it has been reported that the susceptibility of $P$. falciparum to artemisinin derivatives is declining in several parts of the world [6]. Laboratory studies have shown that genetically stable and transmissible artemisinin-resistant rodent malaria parasite could be selected through prolonged exposure of drug-sensitive lines to low and increasing levels of artemisinin [7].

Molecular markers are recommended as the earliest technique to detect emerging drug resistance; therefore, the identification and monitoring of genes and mutations, which correlate with resistance to artemisinin and its derivatives, are essential for the evaluation and monitoring of ACT. Previous studies on P. falciparum have provided evidence that few genes have been associated with artemisinin resistance and these genes are sarcoplasmic/ endoplasmic reticulum $\mathrm{Ca}^{2+}$-ATPase6 (pfatpase6) [8,9], pfmdr1 [10-13] and P. falciparum multidrug resistance protein 1 [14-18]. However, PfATP6 protein might be the major target of artemisinin in P. falciparum, as the drug completely inhibits the activity of this protein $[8,9]$. Moreover, recent studies performed with both eukaryotic models and field isolates have proposed that single nucleotide polymorphisms (SNPs) in the pfatpase6 gene are involved in altered in vitro sensitivity to artemisinin or its derivatives $[9,19,20]$. Also, different studies have previously shown that pfatpase6 contains a number of SNPs [21-23] and four of them (L263E, E431K, A623E, and S769N) have been reported to be associated with a considerable increase in artemether IC50 [19]. It has been also found that the pfatpase6 S769N mutation is strongly associated with raised artemether IC50 in P. falciparum isolates from French Guiana [19]. Besides, it has been suggested that the mutation at L263E codon is involved in the inhibition of PfSERCA by artemisinin [9,19] and allelic exchange study showed reduced susceptibility to artemisinin in parasites expressing the L263E allele [21]. The combination of two additional SNPs, E431K and A623E, was identified in one clinical isolate from Senegal that showed a considerable increase in artemether IC50 [19]. Moreover, other polymorphisms have been identified in pfatpase6 gene: I89T in Thailand [24], H243Y in Central Africa [25] and silent mutation T2694A in São Tomé and Principe [26]. In 2008, Dahlström and co-workers [22], who studied $P$. falciparum isolates from East and West Africa, identified 33 SNPs; three of which were found in a frequency higher than 5\% at codons E431K, N569K and A630S.

In October 2007, Iran has switched its first-line treatment policy for uncomplicated falciparum cases to the use of ACT. Nowadays, there is no other anti-malarial drug to replace the artemisinin derivatives; thus, an urgent global priority is needed to prevent potentially emergence and spread of artemisinin resistance. The main goal of the present study was to examine the mutation(s) in the atpase6 gene of $P$. falciparum isolates unexposed and exposed to ACT prior and four years after the adoption of ACT as the first-line anti-malarial drug in hypoendemic malaria settings. In fact, this study attempted to determine whether drug pressure imposed by continuous deployment of ACT causes a potential selection of mutation(s) in pfatpase 6 gene or not, in particular, candidate mutations (TTA)L263E(GAA), (GAA)E431K(AAA), (GCA)A623E (GAA) and (AGT)S769N(AAT).

\section{Methods}

\section{Study area and sample collection}

In this study, blood samples were collected from different health centers of Chabahar district in Sistan and Baluchistan province in the south-eastern part of Iran. In this area, malaria transmission is year-round with two peaks: the first peak occurs during May to August and the second peak mostly happens around October to November and the majority of the cases are infected with Plasmodium vivax. Blood samples $(\mathrm{n}=226)$ were collected from uncomplicated $P$. falciparum-infected 
patients, aged from 2 to 70 years old, during 2003 to 2010. The inclusion criteria were the presence of fever for the preceding $48 \mathrm{~h}$ (axillary temperature $\geq 37.5^{\circ} \mathrm{C}$ ), mono-infection with $P$. falciparum, no intake of antimalarial drugs for the preceding four weeks and no signs of complications. One milliliter venous blood was collected from $P$. falciparum-infected patients prior to treatment based on the National Guideline for treating malaria (CQ from 2003 to 2005, CQ-SP from 2005 to 2007 and SP-artesunate from 2007 onward). All blood samples were collected in a tube containing EDTA, stored at $4^{\circ} \mathrm{C}$, and then transported to the main laboratory in Tehran. Furthermore, a written informed consent was obtained from all patients (adults or parents/legal guardians of children) who were participated in the study and an ethics approval was obtained from the Ethical Review Committee of Research of Institut Pasteur, Iran.

Isolation of parasite genomic DNA from laboratory clones and field isolates of $P$. falciparum

Parasite DNA was extracted from $300 \mu \mathrm{L}$ blood samples of either continuous culture of K1 laboratory strains or field isolates of $P$. falciparum using the commercially available DNA purification kit (Promega, Madison, WI, USA), and kept at $-20^{\circ} \mathrm{C}$ until use. DNA of P. falciparum was detected by nested-PCR amplification of the small sub-unit ribosomal ribonucleic acid (18ssrRNA) genes as described previously [27]. The DNA was resuspended in a Tris-EDTA buffer (10 mM Tris- $\mathrm{HCl}, \mathrm{pH} 8.0,0.1 \mathrm{mM}$ EDTA) and kept at $-20^{\circ} \mathrm{C}$ until use.

\section{Nested PCR-RFLP and sequencing}

The fragment of pfatpase6 gene was amplified by nested PCR with oligonucleotide primers and the cycling condition has been demonstrated in Table 1. Briefly, amplification was carried out in a final volume of $25 \mu \mathrm{L}$, including $1 \mu \mathrm{L}$ nest1 PCR product as template, $250 \mathrm{nM}$ primers,
$10 \mathrm{mM}$ Tris- $\mathrm{HCl}$ (pH 8.3), $50 \mathrm{mM} \mathrm{KCl,} 2 \mathrm{mM} \mathrm{MgCl}_{2}$, $125 \mu \mathrm{M}$ each of the four deoxynucleotide triphosphates and 0.4 U Taq polymerase (Invitrogen, Carlsbad, CA, USA). Secondary PCR products were digested by four enzymes: ApoI (Fermentas, Vilnius, Lithuania), MBoII (Fermentas, Vilnius, Lithuania), Cac81 (New England Biolab, Beverly, MA, USA) and DdeI (Fermentas, Vilnius, Lithuania) and were used to identify mutations at positions L263E, E431K, A623E, and S769N, respectively (Table 1). Secondary PCR products and digestion fragments were resolved by electrophoresis on a 1.5 and 1.5-3\% agarose gel, respectively.

Based on PCR-RFLP results, 40 samples $(n=20$, 20032006; $\mathrm{n}=20,2007-2010$ ) were selected for sequencing analysis of the entire pfatpase6 gene. Therefore, $4032 \mathrm{bp}$ (nt $=-66$ to 3966 in GenBank, accession no. AB121053) of pfatpase6 gene, including all reported artemisininresistant SNPs, was amplified by using the oligonucleotide primers and the cycling condition has been described in Table 2. Each pair of primers was designed to overlap 70 to 100 bp to cover all sequencing region. The amplified fragments were gel purified using the QIAquick Gel Extraction kit (Qiagen, Hilden, Germany) following the manufacturer's instructions. Direct sequencing of the DNA fragments was performed in both directions for each PCR product using the dideoxy chain termination procedure (Chemistry V3.1, Applied Biosystems) and also the 3730XL DNA analyzer (Applied Biosystems) by MilleGen sequencing service (Labege, France). Nucleotide and amino acid sequences were aligned and compared with wild-type sequences (accession no. AB121053) using CLUSTAL W.

\section{Estimation of the copy numbers of pfatpase6 gene by real-time PCR assay}

The gene copy number was assessed by real-time quantitative PCR (RT-qPCR) using a StepOne ${ }^{\text {Tm }}$ (Applied

Table 1 PCR/RFLP profiles used for genotyping of the pfatpase6 gene

\begin{tabular}{|c|c|c|c|c|c|c|c|}
\hline \multicolumn{4}{|c|}{ PCR Reaction } & \multicolumn{4}{|c|}{ RFLP Reaction } \\
\hline \multirow[t]{2}{*}{ Reaction } & \multirow[t]{2}{*}{ Primer Sequence $\left(5^{\prime} \rightarrow 3^{\prime}\right)$} & \multirow{2}{*}{$\begin{array}{c}\text { Ann } \\
\text { (Time) }\end{array}$} & \multirow{2}{*}{$\frac{\text { Size }}{(b p)}$} & \multirow[t]{2}{*}{ Position } & \multirow{2}{*}{$\begin{array}{l}\text { Restriction } \\
\text { Enzyme }\end{array}$} & \multicolumn{2}{|c|}{ Product Size } \\
\hline & & & & & & (bp) & \\
\hline \multirow[t]{2}{*}{ Nest-1A } & F: TTGGTAATAAAACTCCCGC & $58\left(2^{\prime}\right)$ & 948 & - & - & - & - \\
\hline & R: TATTCCTCTTAGCACCACTCC & & & & & & \\
\hline \multirow[t]{2}{*}{ Nest-2A } & F: TCATCTACCGCTATTGTATG & $60\left(1^{\prime}\right)$ & 775 & L263E & Apo 1 & $L: 775$ & $E: 633+142$ \\
\hline & R: TCCTCTIAGCACCACTCC & & & E431K & MBoll & $\mathrm{E}: 299+241+117+69+49$ & $K: 416+241+69+49$ \\
\hline \multirow[t]{2}{*}{ Nest-1B } & F: AAGAAGGATAAATCACCAAG & $55\left(1^{\prime}\right)$ & 725 & - & - & - & - \\
\hline & R: AAATACACGTATACCAGCC & & & & & & \\
\hline \multirow[t]{2}{*}{ Nest-2Ba } & F: TAACCATTCTAATTATACTACAGC $\underline{\mathbf{g}}$ CAGG & $60\left(1^{\prime}\right)$ & 141 & A623E & Cac8 I & $A: 114+27$ & E: 141 \\
\hline & R: TGTGTTGATGTGGTATTTATITATTACCC & & & & & & \\
\hline \multirow[t]{2}{*}{ Nest-2Bb } & F: AGAACAtTTAGCTITGCTTATAAAAAAç & $60\left(1^{\prime}\right)$ & 164 & S769N & Ddel & S: $136+28$ & $N: 164$ \\
\hline & R: ATATGGCATAATCTAATTGCTCTTCCTAC & & & & & & \\
\hline
\end{tabular}


Table 2 Sequences of oligonucleotide primers and cycling conditions used for full-length pfatpase6 sequencing

\begin{tabular}{|c|c|c|}
\hline Primer Sequence $\left(5^{\prime} \rightarrow 3^{\prime}\right)$ & Ann (min) & Size (bp) \\
\hline $\begin{array}{l}\text { F1: ATTATATCTITGTCATTCGTG } \\
\text { R1: TTGTAAAGGTGTTGAGTATC }\end{array}$ & $55\left(1^{\prime}\right)$ & 840 \\
\hline $\begin{array}{l}\text { F2: TCATCTACCGCTATTGTATG } \\
\text { R2: TCCTCTTAGCACCACTCC }\end{array}$ & $60\left(1^{\prime}\right)$ & 775 \\
\hline $\begin{array}{l}\text { F3: AAGTGTTGAGACGTTAGGATG } \\
\text { R3: TTGATGATTGTACAGGTGTGG }\end{array}$ & $55\left(1^{\prime}\right)$ & 698 \\
\hline $\begin{array}{l}\text { F4: TGGAGACAGTACCGAATTAGC } \\
\text { R4: TCTTCCTACATATTTACGTGGTG }\end{array}$ & $60\left(1^{\prime}\right)$ & 814 \\
\hline $\begin{array}{l}\text { F5: ATTGTAAAGGTGCACCTGAG } \\
\text { R5: TTACCTAGTGCTGTTGCTGG }\end{array}$ & $60\left(1^{\prime}\right)$ & 922 \\
\hline $\begin{array}{l}\text { F6: TAGTAATATAGGAGAAGTTGC } \\
\text { R6: TGTATGTTGTGTGTGTGC }\end{array}$ & $60\left(1^{\prime}\right)$ & 578 \\
\hline $\begin{array}{l}\text { F7: ATCCACCAGAACATGACG } \\
\text { R7: TCTTGGTTCTTTGCTCTTC }\end{array}$ & $60\left(1^{\prime}\right)$ & 760 \\
\hline
\end{tabular}

Biosystems $^{\mathrm{TM}}$ ) in the presence of SYBR green. Oligonucleotide primers (F: TTGCTGCTATACCAGAAGGATTGC and R:TGTTGTCATTTGATTTGTTGTAAGGG) were manually designed (accession no. AB121053) and verified by both Primer Express ${ }^{\circledR}$ Software for real-time PCR (Version 3.0, Applied Biosystems ${ }^{\mathrm{TM}}$ ) and Gene Runner (Version 3.05). Amplification was carried out in triplicate using the default thermocycler program in a total volume of $20 \mu \mathrm{l}$ in a 48 -well plate (Applied Biosystems ${ }^{\mathrm{TM}}$ ), containing $10 \mu \mathrm{l} 1 \times \mathrm{SYBR}^{\circledR}$ Green PCR Master Mix (Applied Biosystems, Warrington, UK), $0.75 \mu \mathrm{l}$ of each of the sense and anti-sense primers $(10 \mu \mathrm{M}), 5 \mu \mathrm{L}$ genomic DNA (20 ng) and $3.5 \mu \mathrm{L}$ water, with amplicon size of $179 \mathrm{bp}$. The program was: pre-incubation at $95^{\circ} \mathrm{C}$ for $10 \mathrm{mins}$, followed by 40 cycles at $95^{\circ} \mathrm{C}$ for 15 seconds and at $60^{\circ} \mathrm{C}$ for $1 \mathrm{~min}$. A PCR negative control with no template was used to check the presence of the dimmers and finally an electrophoresis was used once at the end of the first optimization plate to confirm that a single product of the target gene is present. In this study, the $2^{-\Delta \Delta C t}$ method for relative quantification was used to estimate the copy numbers of pfatpase6 gene. In this method, to estimate gene copy numbers in unknown samples, at least one calibrator consisting of template DNA with known copies of pfatpase6 (P. falciparum K1 with one copy of atpase6) and a house-keeping gene of constant copy number in all samples ( $p f-\beta$-tubulin gene) are required. The formula for the estimation of gene copy numbers in clinical isolates of $P$. falciparum is as followed: ${ }^{\Delta \Delta} C_{t}=\left(C_{t} \text { target gene }-C_{t} p f-\beta \text {-tubulin }\right)_{\text {unknown sample }}$ $\left(C_{t} \text { target gene }-C_{t} p f-\beta \text {-tubulin }\right)_{K 1}$. Then, the result for each sample was expressed in $\mathrm{N}$-fold changes in unknown samples $\left(2^{-\Delta \Delta C t}\right)$. A minimum of two experiments was carried out for each sample and the results were expressed as the $\mathrm{N}$-fold copy number of a given gene relative to
P. falciparum $\mathrm{K} 1$, by calculating the mean between the two experiments. In the case where $\mathrm{N}$-fold was between 0.5 and $1.6(0.5<\mathrm{N}$-fold < 1.6), it was accepted that the test sample harbored a single copy of the target gene.

In the present study, $\beta$-tubulin as a house-keeping gene was amplified using the primers described previously [28]; F: TCGTCAACTTCCTTTGTGGA and R: TCCCATTCCCACGTTTACAT). To normalize quantitative data in each reaction, all samples were analyzed in triplicate within each LightCycler run and the average value was accepted if the standard deviation was lower than 0.24. The genomic DNA samples used were the same as those used for gene amplification and sequencing. The purity and quantity of DNA were determined by UV spectrophotometry. To determine RT-qPCR efficiencies, standards consisting of 2-fold serial dilutions of genomic DNA were freshly prepared from concentrated stocks for each experiment. Genomic DNAs in the range of 64 to $1 \mathrm{ng}$ were used as quantification standards for the LightCycler calibration curve. Then, amplifications were performed on the same diluted samples using primers for the reference ( $p f-\beta$-tubulin) and the target genes. The average $C_{t}$ was calculated for both reference and target genes, the $\Delta C_{t}\left(C_{t}\right.$ target gene $-C_{t} p f-\beta$-tubulin $)$ was determined and the log DNA dilution versus $\Delta C_{t}$ was plotted. The efficiency of the PCR should be $90-100 \%$ $(-3.6>$ slope $>-3.1)$. If the absolute value of the slope was close to zero $(0.1)$, the efficiencies of the target and reference genes were similar, and thus the $\Delta \Delta C_{t}$ calculation could be applied.

\section{Statistics}

All statistical analyses were performed using SPSS statistical package (version 16.0). Frequencies of mutations and haplotypes among the groups were compared using the $X^{2}$ test. $P<0.05$ was considered statistically significant.

\section{Results}

\section{Sample characteristics}

In this investigation, pfatpase6 gene was successfully amplified in all field samples $(\mathrm{n}=226)$. Of $226 \mathrm{P}$. falciparum isolates, 35 samples were collected before the adoption of ACT as the first-line anti-malarial drug in Iran during 2003-2006 with no artemisinin pressure. Also, 49 of 226 samples were collected in 2007, when the artemisinin pressure was very low. Although SPartesunate was selected to replace CQ-SP in the study areas in year 2007 all malaria settings in Iran undoubtedly used SP-artesunate as the first-line therapy in 2008. Other 142 of 226 samples were collected after the full adoption of SP-artesunate in Iran. 


\section{Prevalence of pfatpase6 SNPs and allelic distributions}

All 226 P. falciparum samples were successfully genotyped. Surveillance of pfatpase6 SNPs within positions L263E, E431K, A623E, and S769N indicated no (0/226), $18.6 \%(42 / 226)$, no $(0 / 226)$, and $2.2 \%(5 / 226)$ prevalence of pfatpase6, respectively (Table 3 ). The majority of the patients $(80 \%, 181 / 226)$ was found to carry wild type while single mutant haplotype $\left(\mathrm{L}_{263} \underline{\mathbf{K}}_{431} \mathrm{~A}_{623} \mathrm{~S}_{769}\right)$, as the second predominant allele, was detected in $16.4 \%$ (37/226) studied isolates (Table 3).

According to the year of sample collection, before 2007 , the prevalent haplotypes were wild type (77\%) and $\mathrm{L}_{263} \underline{K}_{431} \mathrm{~A}_{623} \mathrm{~S}_{769}$ (23\%); however, the most frequent haplotype in 2007-2010 was wild type (80.6\%) (Table 3 ). In addition, the number of haplotypes increased from 2 to 6 after ACT adoption in Iran (Table 3). Before and after the introduction of ACT, the prevalence of pfatpase6 E431K mutation in Sistan and Baluchistan province was 23\% (8/35) and 17.8\%, (34/191) respectively (Table 3). However, S769N mutation was not detected in any unexposed isolates, but found in $2.6 \%$ (5/191) of the exposed isolates (Table 3).

\section{Sequencing the full length of pfatpase6 gene}

The pfatpase6 gene of 4032 bp in length was successfully sequenced from the PCR products of 4060 bp by using 7 overlapping paired primers. Both non-synonymous and synonymous mutations were detected at different frequencies in comparison with the reference sequence (accession no. AB121053) as shown in Table 4. Sequencing analysis of samples confirmed the RFLP results. In addition, nine different non-synonyumous mutations at codons 89 (87.5\%), 230 (\%2.5), 355 (15\%), 431 (57.5\%), 569 (87.5\%), 630 (100\%), 683 (97.5\%), 769 (6.5\%) and $870(2.5 \%)$ were detected in high frequency among both unexposed and exposed $P$. falciparum isolates $\left(X^{2}\right.$ test, $P>0.05$ ) (Table 4).

\section{Copy number of pfatpase6 gene}

In this study, to obtain optimal efficiency, RT-qPCRs were first optimized for each gene by both PCR reagent concentrations and primers and for each gene (including target, house-keeping and reference genes), PCR efficiencies were obtained for about $95 \%$ of all cases (data not shown). Regarding the further validity of the RT-qPCR assay, the copy number of pfatpase6 gene was compared with the laboratory clone $P$. falciparum $\mathrm{K} 1$ with only one copy number for the mentioned gene. After finding the optimal conditions for pfatpase6 gene, the estimated gene copy number of all examined field isolates was 1.0 equal to the reference isolate $\mathrm{K} 1$.

\section{Discussion}

ACT is the mainstay of global efforts to control $P$. falciparum malaria, but suspected failure of artemisinin is the most important obstacle towards malaria control and elimination [5]. At the present, no alternative classes of anti-malarial drugs are available to replace the artemisinin derivatives; hence, an urgent global priority is needed to prevent potentially the emergence and spread of artemisinin resistance. To achieve this goal, determining the molecular mechanism of artemisinin and its derivative resistance is very important. Therefore, the present molecular analysis provides, for the first time, baseline information on putative mutations (L263E, E431K, A623E and S769N) associated with artemisinin resistance in $P$. falciparum population unexposed and exposed to ACT in low endemic areas of Iran. In this study, by using nested PCR-RFLP followed by sequencing analysis, neither pfatpase6 L263E nor A623E mutations was detected among P. falciparum isolates unexposed (before 2007) and exposed (after 2007) to ACT. In addition, L263E mutation was never found in field isolates $[3,19,20,22,23,26,29-33]$, similar to the present finding, and its association with artemisinin resistance needs more studies to be confirmed.

Table 3 Frequency distribution of putative SNPs and haplotypes of pfatpase6 gene in 226 P. falciparum isolates unexposed (<2007) and exposed (>2007) to ACT

\begin{tabular}{|c|c|c|c|c|c|c|c|c|}
\hline \multirow{3}{*}{$\begin{array}{l}\text { Gene } \\
\text { Haplotype }\end{array}$} & \multicolumn{4}{|c|}{ pfatpase6 } & \multicolumn{3}{|c|}{ Year } & \multirow{3}{*}{$\frac{\text { Total }}{n=226(\%)}$} \\
\hline & \multirow[t]{2}{*}{ L263E } & \multirow[t]{2}{*}{ E431K } & \multirow[t]{2}{*}{ A623E } & \multirow[t]{2}{*}{ S769N } & \multirow{2}{*}{$\frac{<2007^{*}}{\mathrm{n}=35(\%)}$} & \multirow{2}{*}{$\frac{2007^{* *}}{n=49(\%)}$} & \multirow{2}{*}{$\frac{2008-2010^{* * *}}{n=142(\%)}$} & \\
\hline & & & & & & & & \\
\hline LEAS & $\mathrm{L}$ & $E$ & $A$ & $S$ & $27(77)$ & $44(89.8)$ & $110(77.5)$ & $181(80)$ \\
\hline LI & $\mathrm{L}$ & $\underline{K}$ & $A$ & $S$ & $8(23)$ & $4(8.2)$ & 25 (17.6) & 37 (16.4) \\
\hline $\mathrm{LEA}(\underline{\mathbf{S N}})$ & $\mathrm{L}$ & $E$ & A & SN & - & $1(2)$ & $2(1.4)$ & $3(1.3)$ \\
\hline$L(\underline{E K}) A S$ & $\mathrm{~L}$ & EK & $A$ & $\mathrm{~S}$ & - & - & $3(2.1)$ & $3(1.3)$ \\
\hline$\underline{\mathrm{K}} \mathrm{A}(\underline{\mathbf{S N}})$ & $\mathrm{L}$ & $\underline{K}$ & A & SN & - & - & $1(0.7)$ & $1(0.5)$ \\
\hline $\mathrm{L}(\mathbf{E K}) \mathrm{A}(\mathbf{S N})$ & $\mathrm{L}$ & EK & $A$ & SN & - & - & $1(0.7)$ & $1(0.5)$ \\
\hline
\end{tabular}

* Unexposed $P$. falciparum isolates to ACT.

** Exposed to ACT with high pressure.

*** Exposed to ACT introduction of ACT as first-line anti-malarial therapy for 4 years 
Table 4 Sequence analysis of SNPs in full-length pfatpase6 among $40 \mathrm{P}$. falciparum clinical isolates unexposed $(n=20)$ and exposed $(n=20)$ to ACT

\begin{tabular}{|c|c|c|c|c|c|}
\hline \multicolumn{6}{|c|}{ A: Nonsynonymous } \\
\hline \multicolumn{4}{|c|}{ Position } & \multirow{2}{*}{$\frac{\leq 2007}{n=20}$} & \multirow{2}{*}{$\frac{>2007}{n=20}$} \\
\hline nt & aa & & Codon & & \\
\hline \multirow[t]{2}{*}{266} & 89 & $T$ & AcA & 0.25 & 0 \\
\hline & & I & AtA & 0.75 & 1 \\
\hline \multirow[t]{2}{*}{689} & 230 & I & AtC & 0.95 & 1 \\
\hline & & $\mathrm{T}$ & $\mathrm{AcC}$ & 0.05 & 0 \\
\hline \multirow[t]{2}{*}{1063} & 355 & । & aTA & 1 & 0.7 \\
\hline & & L & tTA & 0 & 0.3 \\
\hline \multirow[t]{2}{*}{1291} & 431 & E & gAA & 0.45 & 0.40 \\
\hline & & K & aAA & 0.55 & 0.60 \\
\hline \multirow[t]{2}{*}{1707} & 569 & K & $\mathrm{AAa}$ & 0.25 & 0 \\
\hline & & $\mathrm{N}$ & AAt & 0.75 & 1 \\
\hline \multirow[t]{3}{*}{1888} & 630 & $\mathrm{~T}$ & $\mathrm{aCT}$ & 0 & 0 \\
\hline & & $\mathrm{H}$ & $\mathrm{gCT}$ & 0.95 & 1 \\
\hline & & $S$ & $\mathrm{tCT}$ & 0.05 & 0 \\
\hline \multirow[t]{2}{*}{2049} & 683 & K & $\mathrm{AAa}$ & 0 & 0.05 \\
\hline & & $\mathrm{N}$ & AAt & 1 & 0.95 \\
\hline \multirow[t]{2}{*}{2306} & 769 & $S$ & $\mathrm{AgT}$ & 1 & 0.87 \\
\hline & & $\mathrm{N}$ & $\mathrm{AaT}$ & 0 & 0.13 \\
\hline \multirow[t]{2}{*}{2610} & 870 & $\mathrm{~F}$ & $T \mathrm{Tt}$ & 1 & 0.95 \\
\hline & & L & Tाa & 0 & 0.05 \\
\hline
\end{tabular}

\begin{tabular}{lccccc}
\hline B: Syonymous & & & & & \\
\hline 981 & 327 & $\mathrm{~A}$ & $\mathrm{GCa}$ & 0.05 & 0 \\
\hline 1449 & & $\mathrm{~A}$ & $\mathrm{GCt}$ & 0.95 & 1 \\
\hline & 483 & $\mathrm{~N}$ & $\mathrm{AAc}$ & 0.2 & 0 \\
\hline 2694 & & $\mathrm{~N}$ & $\mathrm{AAt}$ & 0.8 & 1 \\
\hline & 898 & $\mathrm{I}$ & $\mathrm{Ata}$ & 0.8 & 0.95 \\
\hline 2703 & & $\mathrm{I}$ & $\mathrm{ATt}$ & 0.2 & 0.05 \\
\hline & 901 & $\mathrm{~V}$ & $\mathrm{GTa}$ & 0.95 & 1 \\
\hline 3090 & & $\mathrm{~V}$ & $\mathrm{GTt}$ & 0.05 & 0 \\
\hline & 1030 & $\mathrm{~K}$ & $\mathrm{AAa}$ & 0.05 & 0.05 \\
\hline 3093 & & $\mathrm{~K}$ & $\mathrm{AAg}$ & 0.95 & 0.95 \\
\hline & 1031 & $\mathrm{C}$ & $\mathrm{TGc}$ & 0.95 & 1 \\
\hline 3309 & & $\mathrm{C}$ & $\mathrm{TGt}$ & 0.05 & 0 \\
\hline & 1103 & $\mathrm{Y}$ & $\mathrm{Tat}$ & 0.95 & 1 \\
\hline
\end{tabular}

nt: nucleotide.

aa: amino acid.

Concerning $\mathrm{E} 431 \mathrm{~K}, 23 \%$ of the isolates harbored this SNP in the collected samples before 2007; however, $17.8 \%$ were detected in $P$. falciparum samples exposed to artesunate after 2007 . The pfatpase 6 E431K mutation has been suggested to be associated with increased artesunate IC50 in Senegal [19] and this SNP has also been reported from African, Asian and South American $P$. falciparum isolates. In the present findings we found a high frequency of this SNP among P. falciparum population unexposed and exposed to artesunate, indicating that this SNP is unlikely associated with artemisinin resistance. Furthermore, the most prevalent haplotype was wild type with a frequency of $77 \%$ before 2007 and $80.6 \%$ after 2007. The second most frequent haplotype was $\mathrm{L}_{263} \underline{K}_{431} \mathrm{~A}_{623} \mathrm{~S}_{769}$ with $23 \%$ and $15.2 \%$ frequency before and after ACT adoption in Iran, respectively. In a previous in vitro study, this haplotype with single mutation was sensitive to dihydroartemisinin [33] and the results suggested that the high frequency of E431K among Cameroonian P. falciparum isolates might be a warning signal for artemisinin drug resistance. Also, although this mutation in high frequency (overall 18.6\%) was found among Iranian $P$. falciparum isolates, the non-significant prevalence $\left(X^{2}\right.$ test, $\left.P>0.05\right)$ among parasite population unexposed and exposed to ACT suggested that this mutation might have not been selected under artemisinin pressure.

Pfatpase6 S769N mutation has been reported to affect the PASERCA activity with increased artemether IC50 and it was originally found in P. falciparum field isolates from French Guiana [19]. However, it was not reported from China [34], Tanzania [32], Niger [31] and Brazil [35] with a different level of malaria endemicity. In parallel, this mutation was not detected in 35 Iranian $P$. falciparum isolates collected during 2001-2002 when CQ was used as first-line anti-malarial therapy [36]. In addition, in the present investigation, further analysis on $P$. falciparum isolates collected during 2003-2006 (when CQ-SP was used as the first-line treatment) revealed no S769N mutation. Since ACT was used as the first-line treatment for uncomplicated falciparum malaria in Iran (in 2007), the frequency of this mutation has started to increase (2.6\%). Detection of this mutation in only parasite isolates exposed to artesunate might suggest the likely selection of this mutation by artemisinin pressure as the previous study suggested the pfatpase6 S769N mutation as a potential molecular marker for $P$. falciparum resistance to artemether [19]. Also, the most frequent haplotype before and after ACT adoption was wild type, but the number of haplotypes increased from 2 to 6 in parasite isolates unexposed and exposed to ACT, respectively (Notably, parasites carrying pfatpase6 S769N mutation). Nonetheless, recent report by Cui et al. [37], using allele exchange strategy revealed that 3D7 parasite carrying $769 \mathrm{~N}$ mutation was still sensitive to artemisinin and its derivatives. This evaluation was done by in vitro response of transgenic lines to aforementioned drugs [37]. Although this result argue against the predicted role of pfatpase $769 \mathrm{~N}$ in resistance to artemisinin and its derivatives, but many variables including genetic backgrounds of the parasites may significantly influence on parasite resistance to various anti-malarial drugs [38-42]. Therefore, 
due to the conflicting data reported by different studies $[19,37$, present study] the role of this candidate mutation in artemisinin and its derivative resistance needs further study.

In conclusion, the pfatpase6 genotype and its copy number might make early warning signals for the emergence of ACT resistance and provide baseline data for anti-malarial drug policy. Until now, there is no evidence for assuming that artemisinin resistance has occurred in Iran (Iranian Center for Disease Management and Control, surveillance report, unpublished). Therefore, the present results suggest that, to confirm and distinguish a mutation associated with artemisinin resistance, more studies are required among $P$. falciparum population unexposed and exposed to ACT from global malaria endemic setting. However, the pfatpase6 S769N mutation needs more awareness for its association with artesunate resistance and its value as a molecular marker for monitoring artemisinin resistance among $P$. falciparum population remains to be validated in areas where ACT has been used for a longer period. Introducing such a molecular tool could support the national and global malaria control and elimination programmes.

\section{Competing interests}

The authors declare that they have no competing interests.

\section{Authors' contributions}

SZ designed the study, developed the experimental protocols, supervised field and lab works, finalized the interpretation of the data and wrote down the manuscript. SH, SP and MA performed the lab work and also helped in analysing the data. ND and AR have also contributed to the analysis of the data and critically reading the content of the manuscript. All authors read and approved the final manuscript.

\section{Acknowledgments}

We acknowledge the co-operation of the Center for Diseases Management and Control (CDMC), particularly Dr. M.M. Gouya. We are also grateful to the Zahedan University of Medical Sciences and staff in the Public Health Department, Chabahar district, Sistan and Baluchistan province for their generous collaboration, for their logistic support in collecting blood samples, microscopy-based malaria diagnosis and reviewing malaria slides in the field. We are indebted to the patients and their families and their willingness to participate in this study. This study was supported by a grant from the Iranian Deputy for Research of the Ministry of Health, and Institut Pasteur, Iran.

\section{Author details}

${ }^{1}$ Malaria and Vector Research Group (MVRG), Biotechnology Research Center (BRC), Pasteur Institut, P.O. Box 1316943551, Tehran, Iran. ${ }^{2}$ Biology Department, Khatam University, Tehran, Iran. ${ }^{3}$ National Programme for Malaria Control, Ministry of Health and Medical Education, Tehran, Iran. ${ }^{4}$ Tehran University of Medical Sciences, School of Public Health, Tehran, Iran.

Received: 8 September 2012 Accepted: 31 October 2012 Published: 9 November 2012

\section{References}

1. Wongsrichanalai C, Pickard AL, Wernsdorfer WH, Meshnick SR: Epidemiology of drug-resistant malaria. Lancet Infect Dis 2002, 2:209-218

2. Yeung S, Pongtavornpinyo W, Hastings IM, Mills AJ, White NJ: Antimalarial drug resistance, artemisinin-based combination therapy, and the contribution of modeling to elucidating policy choices. AmJ Trop Med Hyg 2004, 71:179-186.
3. Dondorp AM, Nosten F, Yi P, Das D, Phyo AP, Tarning J, Lwin KM, Ariey F, Hanpithakpong W, Lee SJ, Ringwald P, Silamut K, Imwong M, Chotivanich K, Lim P, Herdman T, An SS, Yeung S, Singhasivanon P, Day NP, Lindegardh N, Socheat D, White NJ: Artemisinin resistance in Plasmodium falciparum malaria. N Engl J Med 2009, 361:455-467.

4. Noedl H, Se Y, Schaecher K, Smith BL, Socheat D, Fukuda MM: Artemisinin resistance in Cambodia 1 (ARC1) Study Consortium. Evidence of artemisinin-resistant malaria in western Cambodia. N Engl J Med 2008, 359:2619-2620.

5. WHO-GMP update on artemisinin resistance - September 2011. http://www who.int/malaria/arupdate092011.pdf.

6. Yang H, Liu D, Yang Y, Fan B, Yang P, Li X, Li C, Dong Y, Yang C: Changes in susceptibility of Plasmodium falciparum to artesunate in vitro in Yunnan province, China. Trans R Soc Trop Med Hyg 2003, 97:226-228.

7. Afonso A, Hunt P, Cheesman S, Alves AC, Cunha CV, do Rosário V, Cravo P: Malaria parasites can develop stable resistance to artemisinin but lack mutations in candidate genes atpase6 (encoding the sarcoplasmic and endoplasmic reticulum Ca2+ ATPase), tctp, $m d r 1$, and cg10. Antimicrob Agents Chemother 2006, 50:480-489.

8. Eckstein-Ludwig U, Webb RJ, Van Goethem ID, East JM, Lee AG, Kimura M, O'Neill PM, Bray PG, Ward SA, Krishna S: Artemisinins target the SERCA of Plasmodium falciparum. Nature 2003, 424:957-961.

9. Uhlemann AC, Cameron A, Eckstein-Ludwig U, Fischbarg J, Iserovich P, Zuniga FA, East M, Lee A, Brady L, Haynes RK, Krishna S: A single amino acid residue can determine the sensitivity of SERCAs to artemisinins. Nat Struct Mol Biol 2005, 12:628-629.

10. Cowman AF, Karcz S: Drug resistance and the P-glycoprotein homologues of Plasmodium falciparum. Semin Cell Biol 1993, 4:29-35.

11. Lim P, Herdman T, An SS, Yeung S, Singhasivanon P, Day NP, Lindegardh N, Socheat $\mathrm{D}$, White $\mathrm{NJ}$ : Artemisinin resistance in Plasmodium falciparum malaria. N Engl J Med 2009, 361:455-467.

12. Sidhu AB, Uhlemann AC, Valderramos SG, Valderramos JC, Krishna $\mathrm{S}$, Fidock DA: Decreasing pfmdr1 copy number in Plasmodium falciparum malaria heightens susceptibility to mefloquine, lumefantrine, halofantrine, quinine, and artemisinin. J Infect Dis 2006, 194:528-535

13. Duraisingh MT, Jones $P$, Sambou I, von Seidlein L, Pinder M, Warhurst DC: The tyrosine-86 allele of the pfmdr1 gene of Plasmodium falciparum is associated with increased sensitivity to the anti-malarials mefloquine and artemisinin. Mol Biochem Parasitol 2000, 108:13-23.

14. Dahlström S, Ferreira PE, Veiga MI, Sedighi N, Wiklund L, Mårtensson A, Färnert A, Sisowath C, Osório L, Darban H, Andersson B, Kaneko A, Conseil G, Björkman A, Gil JP: Plasmodium falciparum multidrug resistance protein 1 and artemisinin-based combination therapy in Africa. J Infect Dis 2009, 200:1456-1464.

15. Klokouzas A, Tiffert T, van Schalkwyk D, Wu CP, van Veen HW, Barrand MA, Hladky SB: Plasmodium falciparum expresses a multidrug resistanceassociated protein. Biochem Biophys Res Commun 2004, 321:197-201.

16. Mu J, Ferdig MT, Feng X, Joy DA, Duan J, Furuya T, Subramanian G, Aravind L, Cooper RA, Wootton JC, Xiong M, Su XZ: Multiple transporters associated with malaria parasite responses to chloroquine and quinine. Mol Microbiol 2003, 49:977-989.

17. Raj DK, Mu J, Jiang H, Kabat J, Singh S, Sullivan M, Fay MP, McCutchan TF, Su XZ: Disruption of a Plasmodium falciparum multidrug resistanceassociated protein (PFMRP) alters its fitness and transport of antimalarial drugs and glutathione. J Biol Chem 2009, 284:7687-7696.

18. Veiga MI, Ferreira PE, Jörnhagen L, Malmberg M, Kone A, Schmidt BA, Petzold M, Björkman A, Nosten F, Gil JP: Novel polymorphisms in Plasmodium falciparum $A B C$ transporter genes are associated with major ACT antimalarial drug resistance. PLoS One 2011, 6:e20212.

19. Jambou R, Legrand E, Niang M, Khim N, Lim P, Volney B, Ekala MT, Bouchier C, Esterre P, Fandeur T, Mercereau-Puijalon O: Resistance of Plasmodium falciparum field isolates to in-vitro artemether and point mutations of the SERCA-type PfATPase6. Lancet 2005, 366:1960-1963.

20. Menegon M, Sannella AR, Majori G, Severini C: Detection of novel point mutations in the Plasmodium falciparum ATPase6 candidate gene for resistance to artemisinins. Parasitol Int 2008, 57:233-235.

21. Valderramos SG, Scanfeld D, Uhlemann AC, Fidock DA, Krishna S: Investigations into the role of the Plasmodium falciparum SERCA (PfATP6) L263E mutation in artemisinin action and resistance. Antimicrob Agents Chemother 2010, 54:3842-3852. 
22. Dahlström S, Veiga MI, Ferreira P, Mårtensson A, Kaneko A, Andersson B, Björkman A, Gil JP: Diversity of the sarco/endoplasmic reticulum $\mathrm{Ca}$ (2+)-ATPase orthologue of Plasmodium falciparum (PfATP6). Infect Genet Evol 2008, 8:340-345.

23. Jambou R, Martenelli A, Pinto J, Gribaldo S, Legrand E, Niang M, Kim N, Pharath L, Volnay B, Ekala MT, Bouchier C, Fandeur T, Berzosa P, Benito A, Ferreira ID, Ferreira C, Vieira PP, Alecrim MG, Mercereau-Puijalon O, Cravo P: Geographic structuring of the Plasmodium falciparum sarco (Endo) plasmic reticulum I (PfSERCA) gene diversity. PLoS One 2010, 5:e9424.

24. Price RN, Uhlemann AC, Brockman A, McGready R, Ashley E, Phaipun L, Patel R, Laing K, Looareesuwan S, White NJ, Nosten F, Krishna S: Mefloquine resistance in Plasmodium falciparum and increased pfmdr1 gene copy number. Lancet 2004, 364:438-447.

25. Cojean S, Hubert V, Le Bras J, Durand R: Resistance to dihydroartemisinin. Emerg Infect Dis 2006, 12:1798-1799.

26. Ferreira ID, Lopes D, Martenelli A, Ferreira C, Rosario VE, Cravo P: In vitro assessment of artesunate, artemether and amodiaquine susceptibility and molecular analysis of putative resistance-associated mutations of Plasmodium falciparum from Sao Tomé and Principe. Trop Med Int Health 2007, 12:353-362.

27. Snounou G, Viriyakosol S, Zhu XP, Jarra W, Pinheiro L, do Rosario VE, Thaithong S, Brown KN: High sensitivity of detection of human malaria parasites by the use of nested polymerase chain reaction. Mol Biochem Parasitol 1993, 61:315-320.

28. Happi CT, Gbotosho GO, Folarin OA, Sowunmi A, Hudson T, O'Neil M, Milhous W, Wirth DF, Oduola AM: Selection of Plasmodium falciparum multidrug resistance gene 1 alleles in asexual stages and gametocytes by artemether-lumefantrine in Nigerian children with uncomplicated falciparum malaria. Antimicrob Agents Chemother 2009, 53:888-895.

29. Bacon DJ, McCollum AM, Griffing SM, Salas C, Soberon V, Santolalla M, Haley R, Tsukayama P, Lucas C, Escalante AA, Udhayakumar V: Dynamics of malaria drug resistance patterns in the Amazon basin region following changes in Peruvian national treatment policy for uncomplicated malaria. Antimicrob Agents Chemother 2009, 53:2042-2051.

30. Bertaux L, le Quang H, Sinou V, Thanh NX, Parzy D: New PfATP6 mutations found in Plasmodium falciparum isolates from Vietnam. Antimicrob Agents Chemother 2009, 53:4570-4571.

31. Ibrahim ML, Khim N, Adam HH, Ariey F, Duchemin JB: Polymorphism of PfATPase in Niger: detection of three new point mutations. Malar J 2009, 8:28.

32. Mugittu K, Genton B, Mshinda H, Beck HP: Molecular monitoring of Plasmodium falciparum resistance to artemisinin in Tanzania. Malar J 2006, 5:126.

33. Tahar R, Ringwald P, Basco LK: Molecular epidemiology of malaria in Cameroon. XXVIII. In vitro activity of dihydroartemisinin against clinical isolates of Plasmodium falciparum and sequence analysis of the $P$. falciparum ATPase 6 gene. Am J Trop Med Hyg 2009, 81:13-18.

34. Zhang G, Guan Y, Zheng B, Wu S, Tang L: No PfATPase6 S769N mutation found in Plasmodium falciparum isolates from China. Malar J 2008, 7:122.

35. Ferreira ID, Martenelli A, Rodrigues LA, do Carmo EL, do Rosário VE, Póvoa MM, Cravo P: Plasmodium falciparum from Pará state (Brazil) shows satisfactory in vitro response to artemisinin derivatives and absence of the S769N mutation in the SERCA-type PfATPase6. Trop Med Int Health 2008, 13:199-207.

36. Tanabe K, Zakeri S, Palacpac NMQ, Afsharpad M, Randrianarivelojosia M, Kaneko A, Marma ASP, Horii T, Mita T: Spontaneous mutations in the Plasmodium falciparum sarcoplasmic/endoplasmic reticulum $\mathrm{Ca} 2+$ -ATPase (PfATP6) gene among geographically widespread parasite populations unexposed to artemisinin based combination therapies. Antimicrob Agents Chemother 2011, 55:94-100.

37. Cui L, Wang Z, Jiang H, Parker D, Wang H, Su XZ, Cui L: Lack of association of the S769N mutation in Plasmodium falciparum SERCA (PfATP6) with resistance to artemisinins. Antimicrob Agents Chemother 2012, 56(5):2546. doi:10.1128/AAC.05943-11.

38. Briolant S, Pelleau S, Bogreau H, Hovette P, Zettor A, Castello J, Baret E, Amalvict $R$, Rogier $C$, Pradines $B$ : In vitro susceptibility to quinine and microsatellite variations of the Plasmodium falciparum $\mathrm{Na} / \mathrm{H}_{-}$exchanger (pfnhe-1) gene: the absence of association in clinical isolates from the republic of Congo. Malar J 2011, 10:37.

39. Meng H, Zhang $R$, Yang H, Fan Q, Su X, Miao J, Cui L, Yang Z: In vitro sensitivity of Plasmodium falciparum clinical isolates from the China-
Myanmar border area to quinine and association with polymorphism in the Na_/H_exchanger. Antimicrob Agents Chemother 2010, 54:4306-4313.

40. Reed MB, Caruana SR, Batchelor AH, Thompson JK, Crabb BS, Cowman AF: Targeted disruption of an erythrocyte binding antigen in Plasmodium falciparum is associated with a switch toward a sialic acid-independent pathway of invasion. Proc Natl Acad Sci USA 2000, 97:7509-7514.

41. Sidhu $A B$, Valderramos SG, Fidock DA: pfmdr1 Mutations contribute to quinine resistance and enhance mefloquine and artemisinin sensitivity in Plasmodium falciparum. Mol Microbiol 2005, 57:913-926.

42. Valderramos SG, Valderramos JC, Musset L, Purcell LA, Mercereau-Puijalon O, Legrand E, Fidock DA: Identification of a mutant PfCRT-mediated chloroquine tolerance phenotype in Plasmodium falciparum. PLOS Pathog 2010, 6:e1000887.

\section{doi:10.1186/1475-2875-11-373}

Cite this article as: Zakeri et al:: Molecular assessment of atpase6 mutations associated with artemisinin resistance among unexposed and exposed Plasmodium falciparum clinical isolates to artemisinin-based combination therapy. Malaria Journal 2012 11:373.

\section{Submit your next manuscript to BioMed Central and take full advantage of:}

- Convenient online submission

- Thorough peer review

- No space constraints or color figure charges

- Immediate publication on acceptance

- Inclusion in PubMed, CAS, Scopus and Google Scholar

- Research which is freely available for redistribution

Submit your manuscript at www.biomedcentral.com/submit
C) Biomed Central 